\title{
Analysis on infection control of general hospital radiology
}

\author{
Jungsub Shin, Cheolwoo Park*, Byeongkyou Jeon ${ }^{*}$ \\ Department of Radiologic Technology, Sunlin college, \\ Department of Radiologic Technology, Dong-eui Institute of Technology*, \\ Department of Radiologic Technology, Daegu Health College **,

\section{종합병원 영상의학과의 감염관리 대한 분석} \\ 신정섭, 박철우*, 전병규** \\ 선린대학교 방사선과, 동의과학대학교 방사선과*, 대구보건대학교 방사선과**
}

\begin{abstract}
This study aims to find a way to control infection of community radiology effectively by calculating the degree of contamination, culture and identifying the flora in radiology of five general hospitals in Gyeongsangbuk -do.

Staphylococcus, Micrococcus, Pseudomonas stutzeri, Pseudomonas oryzihabitans were identified as surface flora. These are know to be pathogens of hospital acquired infection and there was no radiology-specific flora. Research subject hospitals were conducting similar infection control education but degree of contamination of each hospital showed significant difference. Difference in degree of contamination according to contact sources were analyzed by Contact sources were classified into technologist-using, patients-using and common-using materials. Analysis of each hospital's degree of contamination showed that patient-using materials were significantly more contaminated than technologist-using and common-using materials $(p<0.001)$.

Devices which are similar to each other in monthly average frequency of use showed no significant difference in degree of contamination, but general X-ray devices and chest boards which are used most frequently showed higher degree of contamination than others. In addition, hospital A, B and C which have heavier monthly average caseload showed relatively high degree of contamination on irradiation devices which are used by technologists only or by technologists and patients commonly, office desks and doorpulls.

Hence it is considered that intensity of infection control education should be different according to the degree of monthly average caseload. This study provided an opportunity to aware that technologists' feeling of contamination is crucial for infection control of radiology, and the Accupoint ATP public hygiene monitoring system which was used in this study for measuring the degree of contamination was proved to be an effective measuring device for hospital acquired infection management.
\end{abstract}

Key Words : Hospital infection, Sanitation monitoring system, Digitize infection control 


\section{요 약}

경상북도에 소재한 5 개 종합병원 영상의학과의 오염도를 계수하고, 오염 원인균을 배양하여 동정하고 이를 토대로 지역사회 영상의학과의 효율적인 감염관리 방안을 모색하고자 하였다.

확인된 표면오염 균주는 Staphylococcus, Micrococcus, Pseudomonas stutzeri, Pseudomonas oryzihabitans로 병원 감염의 원인균으로 알려진 균주였고 영상의학과의 오염원으로 특이성을 가진 균주는 없었다. 조사대상 병원은 비슷한 감염관리교육을 실시하고 있었으나 병원별 오염도의 차이는 유의한 차이를 보였다. 조사대상 병원별 접촉원에 따른 오 염도의 차이는 방사선사 사용, 환자사용, 공통사용으로 구분하여 분석한 결과 환자사용이 방사선사사용, 공통사용에 비해 유의하게 높은 오염도를 보였다 $(\mathrm{p}<0.001)$.

병원별 월평균 검사건수의 차이가 적은 장치는 모든 병원에서 유의한 차이를 보이지 않았으나 이에 비해 촬영건수 가 가장 많은 일반촬영장치, 흉부전용촬영대의 오염도가 다른 촬영장치에 비해 오염도가 높았다. 또한 월평균 촬영건 수가 많은 $\mathrm{A}, \mathrm{B}, \mathrm{C}$ 병원은 방사선사가 단독으로 사용하거나 또는 환자와 공통으로 사용하는 방사선조사장치, 사무용책 상, 출입문 손잡이에서 비교적 높은 오염도를 보였다.

중심단어: 병원감염, 공중위생모니터링시스템, 계수감염관리

\section{I. 서론}

병원감염이란 입원당시에 없었던 혹은 잠복하고 있 지 않던 감염이 입원기간 중, 혹은 외과수술환자의 경 우 퇴원 후 30 일 이내에 발생하는 것을 말한다 ${ }^{[1]}$. 병원 감염은 환자뿐 아니라 병원 내에서 발생하는 직원들의

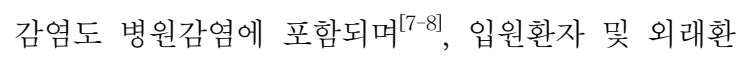
자의 출입이 빈번한 영상의학과는 병에 대한 감수성이 높은 환자들, 검사기구, 위생재료, 보조기구 등 병원 감 염원이 많은 환경으로 환자오염, 교차감염, 접촉감염, 비말감염 등이 쉽게 일어날 수 있는 조건을 갖추고 있 어 적절한 수준의 소독(disinfection)과 멸균(sterilization) 등의 기본적인 감염관리를 하여야 한다 ${ }^{[1-3]}$. 병원감염 은 환자 자신의 구강, 장 등에 정착하고 있는 세균에 의해서 유발되는 내인성 감염과 진료의 목적으로 쓰이 는 여러 가지 처치(요로 혹은 혈관 내 카테터 삽입, 내 시경 검사 등)와 관련하여 의료진의 손에 묻은 균이 직 접 혹은 간접적으로 들어가서 발생하는 외부에 있는 균이 들어와서 생기는 외인성 감염으로 나눌 수 있다. 내인성 감염은 면역기전이 장기간 억제된 환자들에게 환자 자신이 보유한 균으로 인해 발생하는 것으로 예 방이 힘들지만 외인성 감염은 의료종사자들이나 병원
환경이 문제가 되며, 의료종사자들이 주의하거나 병원 환경을 조절함으로써 예방이 가능하고 전체 병원감염 을 약 $30 \%$ 이상 예방할 수 있다 ${ }^{[6],[13]}$.

병원 감염률은 의학의 발전과 병원의 대형화, 감염 에 취약한 노령인구의 증가, 만성 퇴행성 질환자의 증 가, 다수의 항생제 남용, 항암제 및 면역 억제제의 사 용으로 인한 면역부전 환자의 증가, 각종 침습적 의료 처치의 이용확대 등으로 인해 점차 높아지고 있음에 도 불구하고 ${ }^{[4],[11]}$, 병원감염이 체계적으로 관리되지 않 고 있다. 질병관리본부와 대한병원감염관리학회가 전 국 57 개 종합병원 중환자실을 대상으로 병원감염률을 수집해 분석한 결과 2008년 7월부터 2009년 6월까지 1 년 간 3,287 건의 세균감염이 발생한 것으로 나타났고, 최근에는 국내에서도 다제내성균1) 감염 환자가 처음 으로 확인된 가운데 병원 안에서 더 강한 내성을 가진 박테리아에 감염될 수 있다는 불안감이 확산되고 있 다. 보건복지가족부에서는 병원에서 2 차로 감염되는 병원감염에 대한 통제가 강화되는 방안으로 병원 내 감염대책위원회 설치 의무 대상을 현재 300 개 병상 이

1) 항생제에 좀처럼 죽지 않아 일명 슈퍼박테리아 로 불리는 균으로 NDM-1 생성 카바페넴 계열 항생 제에 대한 내성을 획득한 세균(CRE)을 의미한다. 
상의 150 개 의료기관에서 100 개 병상 이상을 가진 1,189 개 의료기관으로 확대하고 의료관련 감염관리 비 용을 보전해주며, 종합병원 원장은 병원감염이 발생할 경우 보건복지가족부장관에게 보고하고 이를 위반하 면 300만원 이하의 과태료를 부과하도록 하는 방안을 고려하는 등 병원감염의 심각성이 공론화 되었고, 병 원감염을 통제하는 관리방안이 필요한 실정이다 ${ }^{[18]}$.

선행연구에서 병원환경은 다른 산업체 환경에 비해 병원감염의 위험이 높은 환경이지만 병원에 종사하는 직원들은 병원감염에 대해 무관심 하고 ${ }^{[14]}$, 환자들은 병원성 미생물 노출에 의해 병원감염에 걸릴 확률이 건강인에 비해 높으며 ${ }^{[9]}$, 영상의학과는 검사의 특성상 환자와의 접촉이 빈번히 일어나 병원감염관리에 각별 히 신경을 써야 함을 보고하였다 ${ }^{[1-2]}$. 경상북도 포항지 역 일 종합병원의 경우 외래환자 1,000 여명, 입원환자 와 보호자 900 여명, 병원 직원 700 여명 등 총 2,600 여 명이 한정된 공간에 밀집하여 생활하고 있고, 영상의 학과는 검사의 특성상 중환자와 일반환자, 보호자의 접촉이 빈번히 일어나 각별한 병원감염관리가 필요한 실정이다.

이에 따라 본 연구에서는 영상의학과의 감염관리를 위한 방안으로 영상의학과 병원감염 현황을 조사하고, 촬영실 및 방사선촬영 보조기구 등의 오염도를 측정 하여 영상의학과의 병원감염관리, 병원감염을 차단하 는 효율적인 감염관리 방안을 모색하고자 하였다.

\section{II. 연구방법}

\section{1. 연구대상}

본 연구의 대상은 2011년 9월1일에서 11월 30일까지 경상북도 $\mathrm{P}$ 시에 소재한 5 개 종합병원 영상의학과 방 사선촬영장비 및 촬영 보조기구, 촬영실로 오염도를 계수하고, 오염 원인균을 배양하여 동정하였다. 오염 도를 분석하기 위하여 환자사용 110 회, 방사선사사용 100 회, 공통사용 60 회, 총 270 회의 오염도를 월평균 촬 영건수와 비교 분석하였다.

\section{2. 분석기기}

오염도 분석 및 오염 균주의 확인을 위하여 Accupoint ATP 공중위생 모니터링 시스템(Neogen, USA), Sampler(Neogen, USA), Transport system( Hangang, Korea) 등을 사용하였고, 미생물 배양 및 균주의 확인 은 삼광의료재단에 의뢰하여 VITEK2 시스템 AST-YS01(BioMérieux, USA)을 사용하였다.

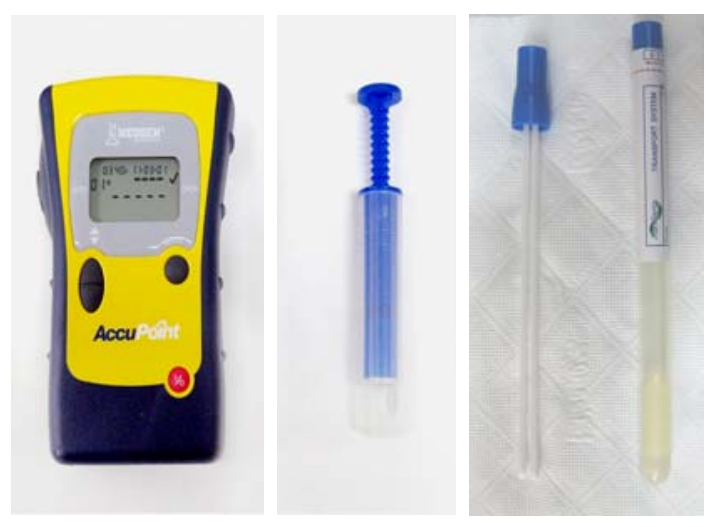

Fig. 1 Accupoint ATP Sanitation Monitoring \& Transport System

\section{3. 오염도 측정}

영상의학과의 오염도는 Neogen사(USA)의 오염도 측정 장비인 Accupoint ATP 공중위생 모니터링 시스 템과 함께 전용 Sampler를 $2 \sim 8^{\circ} \mathrm{C}$ 에 냉장보관 후 사용 하였다. 오염도 측정은 표면을 $10 \mathrm{~cm} \times 10 \mathrm{~cm}$ 의 면적을 일정하게 문질러 Accupoint ATP 공중위생 모니터링 시스템으로 $100 \mathrm{~cm}^{2}$ 의 미생물을 계수하였다.

Accupoint ATP 공중위생 모니터링 시스템의 측정원 리는 살아있는 생물이 가지고 있는 ATP에 Luciferin, Luciferase가 반응할 때 빛을 내는 원리를 이용하여 발 광하는 빛의 양을 측정함으로써 단백질의 오염도를 수치화하여 미생물이 계수된다.

\section{4. 오염균주 확인}

오염미생물의 배양 및 균주 확인을 위하여 호기성 및 혐기성균의 검체수송을 위하여 제작된 수송배지에 서 멸균된 면봉을 사용하여 측정기구의 표면을 충분히 
문질러 미생물을 채취하고 채취한 면봉을 튜브에 넣은 후 마개를 닫고 삼광의료재단에 의뢰하여 미생물 자동 화 검사장비 VITEK2 시스템 AST-YS01(BioMérieux, $\mathrm{USA}$ )을 사용하여 오염된 균주를 확인하였다.

\section{5. 자료의 분석}

자료의 분석은 SPSS 12.0 for windows(SPSS Inc., USA)를 이용하여 병원별 오염도의 차이, 환자사용, 방 사선사 사용, 환자 방사선사 공동사용 물품의 오염도 차이를 Student's t-test로 분석하였고, 병원별 오염도의 차이, 촬영건수의 차이는 일변량 분산분석(ANOVA)과 Duncan's test를 실시하여 집단별 성격의 차이를 분석 하였다. 통계적 유의수준은 0.05 이하로 하였다.

\section{III. 연구결과}

\section{1. 오염균주}

연구대상물의 표면에서 확인된 오염미생물의 균주는 표1과 같다. 흥부촬영장치 검출기, 조사스위치, 사무용 테이블, 촬영실 손잡이, 환자테이블, 조영제 주입장치의 표면오염 균주는 Staphylococcus, Micrococcus, Pseudomonas stutzeri, Pseudomonas oryzihabitans로 병원 감염의 원인균으로 알려진 균주였고, 영상의학과의 오 염원으로 특이성을 가진 균주는 없었다.

Staphylococcus 균주는 수술창상감염이나 환자의 피 부 상재균, Micrococcus 균주는 병실내 감염균, Pseudomonas stutzeri 균주는 토양세균, Pseudomonas oryzihabitans 균주는 고인물이나 훍 등 습한 자연환경에 서 발견된다.

Table 1. Microorganisms Identified in department of radiology

\begin{tabular}{cc}
\hline 균주 & 동정검사 \\
\hline Staphylococcus & Coagulase Negat ive, Gram Positive \\
Micrococcus & Gram Negat ive \\
Pseudomonas stutzer i & Gram Negat ive \\
Pseudomonas oryzihabitans & Gram Negat ive \\
\hline
\end{tabular}

\section{2. 접촉원에 따른 오염도 차이}

조사대상 병원별 접촉원에 따른 오염도의 차이는 표2와 같다. 조사대상 병원을 통합하여 방사선촬영장 치 중 방사선 조사장치, 사무용 책상, 조영제 주입장치 등은 방사선사, 촬영실 출입문손잡이, 촬영장치 손잡 이 등은 공동사용, 흉부촬영용장치 턱받침, CT촬영장 치 머리받침대, 촬영용 테이블 등은 환자사용으로 구 분하였다. 환자사용, 방사선사사용, 공통사용으로 구분 하여 평균값의 차이를 분석하였다.

환자사용이 방사선사사용, 공통사용에 비해 유의하 게 높은 오염도를 보였다( $<<0.001)$. 그러나 방사선사 사용군과 공통사용군의 오염도 차이는 유의성이 없었 다. 환자 사용군에서 조사병원 간 편차가 심하여 표준 편차가 높았다.

Table 2. Contamination score and compared with an osculating circles.

(단위: 개/100 $\mathrm{cm}^{2}$ )

\begin{tabular}{ccc}
\hline 접 촉 원 & 오염도 $(\mathrm{M} \pm \mathrm{SD})$ & 표본수(N) \\
\hline 환자(PT) & $9,347 \pm 13,623$ & 110 \\
방사선사(RT) & $3,246 \pm 1714^{* * * *}$ & 100 \\
공통사용(CU) & $3,445 \pm 1,811^{* * *}$ & 60 \\
\hline
\end{tabular}

Significantly different from the PT group by t-test $\left(^{* * *} ; p<0.001\right)$

\section{3. 조사병원에 따른 오염도 차이}

조사병원별 오염도의 차이는 오염도 및 월평균 촬 영건수를 변량으로 일변량 분산분석(ANOVA)을 실시 하고 사후분석으로 Duncan's test를 실시하였다. 그 결 과 오염도의 차이는 병원별로 유의한 차이가 있었다 $(\mathrm{p}<0.05)$. 조사대상 병원별 접촉원에 따른 오염도의 차 이는 표3과 같이 $\mathrm{B}, \mathrm{C}$ 병원과 $\mathrm{A}, \mathrm{D}, \mathrm{E}$ 병원은 통계적으 로 유의한 차이를 보였다. 또한 월평균 촬영건수는 병 원별로 유의한 차이가 있었다( $\mathrm{p}<0.01) . \mathrm{A}, \mathrm{B}$ 병원과 $\mathrm{D}$, $\mathrm{E}$ 병원, $\mathrm{C}$ 병원은 각각 다른 집단군으로 분류되었다. 특 히 C병원은 오염도 및 월평균 촬영건수에서 모든 병 원과 유의한 차이를 보였고, 월평균 촬영건수가 많은 병원이 오염도가 높았다. 
"Journal of the Korean Society of Radiology, Volume 6, Number 5"

Table 3. Frequency number of Radiography and Hospital and compared with contamination score.

(단위: 개/ $100 \mathrm{~cm}^{2}$ )

\begin{tabular}{ccc}
\hline 병원 & 오염도(unit) & 월평균 촬영건수 \\
\hline A & $4,826 \pm 3,206^{\mathrm{b}}$ & $29,142 \pm 634^{\mathrm{a}}$ \\
B & $8,889 \pm 11,198^{\mathrm{a}}$ & $31,087 \pm 1,637^{\mathrm{a}}$ \\
C & $10,391 \pm 15,553^{\mathrm{a}}$ & $41,046 \pm 5,983^{\mathrm{c}}$ \\
D & $2,620 \pm 1,442^{\mathrm{b}}$ & $4,730 \pm 624^{\mathrm{b}}$ \\
E & $2,301 \pm 909^{\mathrm{b}}$ & $3,936 \pm 271^{\mathrm{b}}$ \\
\hline
\end{tabular}

Values with different superscripts in the same row are significantly different $(p<0.05)$ by ANOVA and Duncan's multiple range test.

\section{4. 오염원에 따른 오염도 차이}

조사병원별 오염원의 차이는 장치별 오염도를 변량 으로 일변량 분산분석(ANOVA)을 실시하고 사후분석 으로 Duncan's test를 실시하였다. 그 결과 표4와 같이 조사병원에 따라 오염원의 유의한 차이가 있었다 $(\mathrm{p}<0.05)$.

Table 4. Germs of equipment and Hospital and and compared with contamination score.

(단위: $\times 1,000$ 개 $/ 100 \mathrm{~cm}^{2}$ )

\begin{tabular}{|c|c|c|c|c|c|c|}
\hline 병원 & 촬영테이블 & 흥부촬영대 & 조사장치 & 사무용책상 & 출입문 & CT Table \\
\hline A & $4.4 \pm 2.0^{\mathrm{a}}$ & $10.7 \pm 4.4^{\mathrm{ab}}$ & $5.2 \pm 2.4^{\mathrm{a}}$ & $6.3 \pm 2.8^{c}$ & $3.2 \pm 1.6^{\mathrm{a}}$ & $2.4 \pm 1.3^{\mathrm{a}}$ \\
\hline B & $27.3 \pm 10.7^{\mathrm{b}}$ & $17.3 \pm 7.0^{\mathrm{b}}$ & $3.5 \pm 1.7^{\mathrm{ab}}$ & $2.0 \pm 1.2^{\mathrm{a}}$ & $33.4 \pm 1.7^{\mathrm{a}}$ & $1.8 \pm 1.2^{\mathrm{a}}$ \\
\hline c & $3.4 \pm 1.8^{\mathrm{a}}$ & $43.0 \pm 16.7^{c}$ & $5.2 \pm 2.4^{\mathrm{a}}$ & $5.7 \pm 2.6^{b c}$ & $6.4 \pm 2.9^{b}$ & $2.8 \pm 1.5^{\mathrm{a}}$ \\
\hline D & $1.7 \pm 1.1^{\mathrm{a}}$ & $3.9 \pm 1.9^{\mathrm{a}}$ & $5.1 \pm 2.3^{\mathrm{a}}$ & $4.1 \pm 1.9^{\mathrm{ab}}$ & $2.4 \pm 1.3^{\mathrm{a}}$ & $2.0 \pm 1.2^{\mathrm{a}}$ \\
\hline E & $2.5 \pm 1.4^{\mathrm{a}}$ & $4.4 \pm 2.1^{\mathrm{a}}$ & $2.8 \pm 1.5^{\mathrm{b}}$ & $2.8 \pm 1.5^{\mathrm{a}}$ & $2.2 \pm 1.3^{\mathrm{a}}$ & $1.8 \pm 1.1^{\mathrm{a}}$ \\
\hline
\end{tabular}

Values with different superscripts in the same row are significantly different $(p<0.05)$ by ANOVA and Duncan's multiple range test.

일반촬영장치의 환자테이블은 $\mathrm{B}$ 병원에서, 흉부전용 촬영대는 $\mathrm{B}, \mathrm{C}$ 병원에서, 조사장치는 $\mathrm{A}, \mathrm{C}, \mathrm{D}$ 병원에서, 사무용 책상은 $\mathrm{A}, \mathrm{C}$ 병원에서 출입문 손잡이는 $\mathrm{C}$ 병원 에서 각각 유의한 차이를 보였다. 그러나 CT장치의 테 이블장치는 모든 병원에서 유의한 차이를 보이지 않 았다. 일반촬영장치, 흉부전용촬영 대의 오염도가 다른 촬영장치에 비해 오염도가 높았고, 이들 병원은 월평
균 촬영건수가 많은 병원이었다. 또한 월평균 촬영건 수가 많은 $\mathrm{A}, \mathrm{B}, \mathrm{C}$ 병원은 방사선사가 단독으로 사용 하거나 또는 환자와 공통으로 사용하는 방사선조사장 치, 사무용책상, 출입문 손잡이에서 비교적 높은 오염 도를 보였다.

\section{$\mathrm{IV}$. 고찰}

최근 의학의 발달로 인간의 노령화와 더불어 항생 제 과다사용으로 인한 항생제 내성균 증가 등으로 병 원감염이 증가하고 있고 ${ }^{[5]}$, 최근에는 국내에서도 다제 내성균 감염 환자가 처음으로 확인된 가운데 병원 안 에서 더 강한 내성을 가진 박테리아에 감염될 수 있다 는 불안감이 확산되고 있다. 이로 인해 의료현장의 의 료인들은 이러한 병원감염을 최소화하기 위해 다양한 감염관리 프로그램의 개발과 실천을 경주하고 있으나 입원환자 및 외래환자의 출입이 빈번한 영상의학과는 병에 대한 감수성이 높은 환자들, 검사기구, 위생재료, 보조기구 등 병원 감염원이 많은 환경으로 환자오염, 교차감염, 접촉감염, 비말감염 등이 쉽게 일어날 수 있 는 조건을 갖추고 있다.

이에 본 연구에서는 지역사회의 특정부분에서 구체 적인 감염관리 방안을 모색하고자 경상북도 포항지역 병원 영상의학과를 대상으로 촬영실 및 방사선촬영 보조기구 등의 오염도를 측정하여 영상의학과의 병원 감염관리, 병원감염을 차단하는 효율적인 감염관리 방 안을 모색하고 영상의학과 감염관리의 기초자료를 제 공하고자 하였다.

먼저 영상의학과에서 환자 및 방사선사의 접촉이 빈번한 촬영실 및 촬영장치의 보조기구의 표면에서 확인된 오염미생물의 균주를 확인하였다. 흉부촬영장 치 검출기, 조사스위치, 사무용테이블, 촬영실 손잡이, 환자테이블, 조영제 주입장치의 표면오염 균주는 Staphylococcus, Micrococcus, Pseudomonas stutzeri, Pseudomonas oryzihabitans로 병원감염의 원인균으로 알 려진 균주였고 영상의학과의 오염원으로 특이성을 가 진 균주는 없어 오염균에 대한 별도의 심각성은 없는 것으로 판단되었다.

조사대상 병원별 접촉원에 따른 오염도의 차이는 방사선사 사용, 환자사용, 공통사용으로 구분하여 오 
염도에 따라 오염원의 관리방안을 모색하고자 하였다. 이에 따라 방사선촬영장치 중 방사선 조사장치, 사무 용 책상, 조영제 주입장치 등은 방사선사 사용, 촬영실 출입문손잡이, 촬영장치 손잡이 등은 공동사용, 흉부 촬영용 장치 턱받침, CT촬영장치 머리받침대, 촬영용 테이블 등은 환자사용으로 구분하였다. 그 결과 환자 사용이 방사선사사용, 공통사용에 비해 유의하게 높은 오염도를 보였다 $(\mathrm{p}<0.001)$. 현형 감염관리교육은 손씻 기를 비롯한 방사선사의 위생관리에 높은 비중을 두 고 있으나 환자의 접촉이 불가피한 영상의학과에서는 환자의 접촉부분을 효율적으로 차단하는 시설이나 위 생품의 사용이 중요한 것으로 판단된다.

조사대상 병원은 비슷한 감염관리교육을 실시하고 있었으나 병원별 오염도의 차이는 유의한 차이를 보 였다. 또한 병월별 월평균 촬영건수에서 통계적으로 유의한 차이를 보였다 $(\mathrm{p}<0.01)$. 통계적으로 동질성 집 단을 분류하고자 일변량 분산분석(ANOVA)을 실시하 고 사후분석으로 Duncan's test를 실시한 결과 오염도 의 차이, 촬영건수의 차이로 조사대상 병원을 분류할 수 있었다 $(\mathrm{p}<0.05)$. 조사대상의 5 개 병원 중 $\mathrm{A}, \mathrm{B}$ 병원 과 $\mathrm{D}, \mathrm{E}$ 병원, $\mathrm{C}$ 병원은 각각 다른 집단군으로 분류되었 다. 특히 C병원은 오염도 및 월평균 촬영건수에서 모 든 병원과 유의한 차이를 보였고, 월평균 촬영건수가 많은 병원이 오염도가 보였다. 따라서 월평균 촬영건 수에 따른 감염관리교육의 차등이 필요한 것으로 판 단된다.

병원별 오염원에 따른 오염도 차이를 확인하고자 일변량 분산분석(ANOVA)을 실시하고 사후분석으로 Duncan's test를 실시한 결과 조사병원에 따라 오염원 의 유의한 차이가 있었다 $(\mathrm{p}<0.05)$. 일반촬영장치의 환 자테이블은 $\mathrm{B}$ 병원에서, 흉부전용촬영 대는 $\mathrm{B}, \mathrm{C}$ 병원에 서, 조사장치는 A, C, D병원에서, 사무용책상은 A, C병 원에서 출입문손잡이는 $\mathrm{C}$ 병원에서 각각 유의한 차이 를 보였다. 그러나 고가의 검사비용으로 병원별 월평 균 검사건수의 차이가 작은 CT장치의 테이블장치는 모든 병원에서 유의한 차이를 보이지 않았다. 이에 비 해 촬영건수가 가장 많은 일반촬영장치, 흉부전용촬영 대의 오염도가 다른 촬영장치에 비해 오염도가 높았 고, 이들 병원은 월평균 촬영건수가 많은 병원이었다. 또한 월평균 촬영건수가 많은 $\mathrm{A}, \mathrm{B}, \mathrm{C}$ 병원은 방사선
사가 단독으로 사용하거나 또는 환자와 공통으로 사 용하는 방사선조사장치, 사무용책상, 출입문 손잡이에 서 비교적 높은 오염도를 보였다. 그러나 임상의 방사 선사는 병원 오염균이 눈에 보이지 않으므로 오염도 를 체감하지 못하고 있으며, 병원감염은 의학적, 윤리 적 및 사회 비용 측면에서 예방활동이 매우 중요함에 도 불구하고 이에 대해 충분한 노력이 잘 기울여지지 는 않고 있다. 본 연구를 수행하는 동안 감염관리의 결과에 방사선사가 오염도를 체감하는 것이 무엇보다 중요함을 인식하는 계기가 되었고, 오염도의 측정도구 로 사용한 Accupoint ATP 공중위생 모니터링 시스템 은 병원감염관리에 유용한 측정도구로 판단되었다. 병 원감염에 관련된 다수의 연구는 감염관리에 대한 지 식과 실천의 상관관계의 연구였다 ${ }^{[10][15-17]}$.

본 연구는 일부 지역병원의 영상의학과에 한정된 연구결과로 일반화하는 데는 어려움이 있지만 병원감 염관리를 계수화하고, 오염원에 따른 오염도 차이를 분석하고 이를 토대로 감염관리의 방안을 모색하는 것이 필요하였다. 또한 선행연구와 병행하여 활성화하 면 감염관리에 대한 지식과 실천도 향상에 높은 효과 가 기대될 것으로 사료되어, 본 연구를 기초로 병원감 염관리에 대한 추가적인 연구의 필요성이 절실함을 알 수 있었다.

\section{$\mathrm{V}$. 요약 및 결론}

이번 연구에서는 2011년 9월1일에서 11월 30일까지 경상북도 $\mathrm{P}$ 시에 소재한 5 개 종합병원 영상의학과 방 사선촬영장비 및 촬영보조기구, 촬영실로 오염도를 계 수하고, 오염 원인균을 배양하여 동정하고 이를 토대 로 지역사회 영상의학과의 병원감염관리, 병원감염을 차단하는 효율적인 감염관리 방안을 모색하고 영상의 학과 감염관리의 기초 자료를 제공하고자 하였고, 다 음과 같은 결론을 얻었다.

첫째, 영상의학과에서 환자 및 방사선사의 접촉이 빈번한 촬영실 및 촬영장치의 보조기구의 표면에서 확인된 오염미생물의 균주를 확인하였다. 확인된 표면 오염 균주는 Staphylococcus, Micrococcus, Pseudomonas stutzeri, Pseudomonas oryzihabitans로 병원감염의 원인 균으로 알려진 균주였고 영상의학과의 오염원으로 특 
"Journal of the Korean Society of Radiology, Volume 6, Number 5"

이성을 가진 균주는 없어 오염균에 대한 별도의 심각 성은 없는 것으로 판단되었다.

둘째, 조사대상 병원은 비슷한 감염관리교육을 실 시하고 있었으나 병원별 오염도의 차이는 유의한 차 이를 보였다. 또한 병월별 월평균 촬영건수에서 통계 적으로 유의한 차이를 보였다( $\mathrm{p}<0.01)$. 조사대상 병원 별 접촉원에 따른 오염도의 차이는 방사선사 사용, 환 자사용, 공통사용으로 구분하여 분석한 결과 환자사용 이 방사선사사용, 공통사용에 비해 유의하게 높은 오 염도를 보였다 $(\mathrm{p}<0.001)$.

셋째, 통계적으로 동질성 집단을 분류하고자 일변 량 분산분석(ANOVA)을 실시하고 사후분석으로 Duncan's test를 실시한 결과 오염도의 차이, 촬영건수 의 차이로 조사대상 병원을 분류할 수 있었고 $(\mathrm{p}<0.05)$, 조사병원별 오염원에서도 유의한 차이가 있었다 $(\mathrm{p}<0.05)$. 고가의 검사비용으로 병원별 월평균 검사건 수의 차이가 작은 CT장치의 테이블장치는 모든 병원 에서 유의한 차이를 보이지 않았으나 이에 비해 촬영 건수가 가장 많은 일반촬영장치, 흉부전용촬영대의 오 염도가 다른 촬영장치에 비해 오염도가 높았다. 또한 월평균 촬영건수가 많은 $\mathrm{A}, \mathrm{B}, \mathrm{C}$ 병원은 방사선사가 단독으로 사용하거나 또는 환자와 공통으로 사용하는 방사선조사장치, 사무용책상, 출입문 손잡이에서 비교 적 높은 오염도를 보였다. 따라서 월평균 촬영건수에 따른 감염관리교육의 차등이 필요한 것으로 판단되었 다.

넷째, 영상의학과 감염관리는 방사선사가 오염도를 체감하는 것이 무엇보다 중요함을 인식하는 계기가 되었고, 이번 연구에서 오염도의 측정도구로 사용한 Accupoint ATP 공중위생 모니터링 시스템은 병원감염 관리에 유용한 측정도구로 판단되었다.

이상의 결과를 종합하면 영상의학과의 오염원으로 특이성을 가진 균주는 없었으나 오염도가 높았고, 월 평균 촬영건수에 따른 감염관리교육의 차등이 필요하 였다. 또한 병원감염관리를 계수화하고, 오염원에 따 른 오염도 차이를 분석하고 이를 토대로 감염관리의 방안을 모색하는 것이 필요하였다. 본 연구의 결과는 선행연구와 병행하여 활성화하면 감염관리에 대한 지 식과 실천에 높은 효과가 기대될 것으로 사료된다.

\section{Reference}

[1] W. A. Rutala, D. J. Weber, "Infection control: the role of disinfection and sterilization", J. Hosp. Infect., Vol. 43, pp.S43-S55, 1999.

[2] Stephen E. Brossette, Alan P. Sprague, J. Michael Hardin, Ken B. Waites, Warren T. Jones, Stephen A. Moser, "Association Rules and Data Mining in Hospital Infection Control and Public Health Surveillance", JAMIA, Vol. 180, No 5, pp.373-381, May, 1998.

[3] W. A. Rutala, D. J. Weber, "Disinfection and sterilization in health care facilities: what clinicians need to know" Clin. Infect. Dis., Vol. 39, pp.702-709, 2004.

[4] 대한병원감염학회, “감염관리지침”. 대한병원감염학회, 1996.

[5] 대한병원감염학회, “병원감염의 증가원인”. 대한병원감염학회, 2002.

[6] Fagon, J. Y., Chasture, A. J., Hance, P., Montravers, A., Novara and Glbert, C., "Nosocominal pneumonia in ventilated patients a cohort study avaluation attributable mortality and hospital stay". Am J Med, Vol. 94, No 3, pp.281-288, 1993.

[7] M. Hassan, H. P. Tuckman, D. S. Kountz, J. L. Kohn, "Cost of hospital-acquired infection", Hosp. Top., Vol .88, pp.82-89, 2010.

[8] B. U. Wu, R. S. Johannes, S. Kurtz, P. A. Banks, "The impact of hospital-acquired infection on outcome in acute pancreatitis", Gastroenterology, Vol. 135, pp..816-820, 2008.

[9] 권대철, 전용웅, 조암, “병원감염 예방을 위한 Film Cassette의 자외선 소독효과”. 대한방사선기술학회지, Vol.24, No 1, pp.27-32, 2001.

[10] 권연숙, 김영아, "간호대학생의 병원감염 예방행위에 대한 인지도와 실천도”. 계명간호과학, Vol. 8, No 1, pp100-112, 2004.

[11] 김대섭(2000), "병원에 종사하는 의료인 및 행정요원의 병원감염 예방지침 중요도에 대한 견해 조사”. 경산대학교대학원 석사학위논문.

[12] 배석환, 이무식, 임창선, 김가중(2008), “촬영 테이블과 IP Cassette의 세균 오염도 측정 및 소독에 관현 연구”. 방사선기술과학, Vol. 31, No 3, pp.229-237, 2008.

[13] 배현직, “병원감염 관리기구의 구성 및 기능”. 대한한의학협회지, Vol. 36, No 10, pp.1165-1172, 1993.

[14] 송인자, 한정식, "병원에 근무하는 의료인의 안전 사고 위험 노출정도 및 안전대책을 위한 정책 연구”. 대한병원협회지, Vol. 24, No 226, pp.4-16, 1995. 
[15] 양인화, “대학병원 종사자의 감염성폐기물에 대한 지식, 태도 및 실천에 관한 연구”. 전남대학교대학원 석사학위논문, 2008.

[16] 이영희, 김인숙,. "중환자실 간호사의 병원감염 예방에 대한 인지도와 수행도에 관한 연구”. 한국모자보건학회지, Vol. 6, No 2, pp.197-210, 2002.

[17] 한상현, “방사선사의 병원감염관리에 대한 인지도와 수행도의 연관성 연구”. 건양대학교 보건복지 대학원 석사학위논문, 2008.

[18] 메디컬투데이, “다제내성균 환자 발생에 병원 감염 불안감 확산”. http://www.mdtoday.co.kr/mdtoday/index.html?no=146136 